\title{
Research on the Difference of the After-tax Net Profit of Listed Companies' Financial Auditing
}

\author{
Xiao-yun Yan \\ Guangdong University of Science \& Technology,Dongguan,China
}

Key words: listed company; finance; audit; post-tax; net profit difference

\begin{abstract}
In the increasingly frequent international economic exchanges, investment and financial markets, and increasingly global production and consumption, accounting language, as an internationally-used "commercial language," is increasingly being valued by a large number of information users. The accounting language must play the role of an international "commercial language", and comparability should be its most important quality feature. Unfortunately, because of various reasons, there is a huge difference between the financial reports prepared by most listed companies in China based on the current domestic accounting standards and related accounting rules and the financial reports adjusted according to international accounting standards. The comparability is very poor. Not only does it bring a lot of inconvenience to users of accounting information, it directly affects the economic interests of investors. It also increasingly becomes the biggest technical obstacle for Chinese listed companies to raise capital overseas and to list directly overseas. This article is based on the above facts and analyzes the difference in net profit after taxation of listed companies.
\end{abstract}

\section{INTRODUCTION}

Due to the large differences in the accounting standards followed by domestic and foreign financial reports, the differences in the cultural and economic background and audit experience of domestic and foreign certified public accountants, and the differences in the auditing standards on which audits are conducted, together with some policy factors Even the reason for the quality of audit practice is that this gap is inevitable. Based on the analysis of the above-mentioned differences, this paper combines the analysis of the discrepancy in the after-tax net profit between the domestic and foreign audit reports, and provides some suggestions for the development and consideration of the back-end audit of Chinese enterprises.

\section{RESEARCH BACKGROUND}

In order to meet the needs of domestic and foreign investors, China's B-share listed companies generally implement dual audit and dual disclosure systems. In other words, China's listed companies should not only comply with the Chinese accounting standards and auditing of financial information, but also follow the international accounting standards and international financial accounting audit information. The difference between these two kinds of information will produce a certain difference in net profit after tax. The degree of difference between the two has an impact on the difference in net profit after taxation. Reviewing previous scholars' research on this issue, their conclusions are quite different.

Personally think that in the B-share auditing market, different accounting firms must have differences in the quality of auditing, so we cannot view the audit quality of all B-share companies as one level. In the research later in this article, the A-share audit was conducted by a well-known accounting firm in China. The B-shares were the responsibility of the four largest international accounting firms. At the same time, domestic and foreign audit reports are selected to analyze the difference in net profit after tax, and to use the data to support the views of this article. 


\section{RESEARCH SUBJECTS AND RESULTS}

\subsection{Research Object}

As of the end of 2015, 104 B-share issuance companies listed on the Shanghai and Shenzhen stock exchanges. A total of 84 companies issued A and B shares at the same time. This article is selected from the 84 public listings that issue $\mathrm{A}$ and $\mathrm{B}$ shares at the same time. Among them, A-shares are audited by domestic accounting firms, and the corresponding B-shares are jointly held by the four largest international accounting firms and their cooperating units. After screening by the above requirements, only 15 samples meet the above conditions. Although the sample size is small, but in order to achieve the research purpose and significance, we should not relax the sample selection conditions in order to increase the sample size.

\subsection{Research results}

\subsubsection{Analysis of Differences}

This article analyzes the differences in the after-tax net profit of the selected 15 sample companies after they have been audited according to different accounting standards from 2013 to 2015. The results are analyzed as follows.

During the period from 203 to 2015, the differences in the after-tax net profit of these 15 sample companies after auditing according to different standards were significant. Among them, in 2013, there were only two differences in audit results according to different standards. The difference was not very large, accounting for $13.13 \%$ of the total sample size. By 2014, there was only a slight difference in net profit after tax, accounting for only $6.67 \%$ of the total sample size. In 2015, this object rose to 5, accounting for $33.33 \%$ of the sample size.

Among the sample companies, the net profit after tax audited according to China's accounting standards and regulations was higher than the net profit after tax adjusted by international accounting staff. This conclusion was even more pronounced in 2005. In 2005, out of 10 listed companies with differences between home and abroad, a total of 8 domestic companies reported net profits greater than overseas reports, which accounted for $53.33 \%$ of the total sample; only 2 companies reported domestic net profits less than overseas reported net profits. It accounts for $13.33 \%$ of the sample wood. In 2004, domestic companies with large internal net profit also accounted for 53.33\% of the net profits. In 2003, the two companies were basically the same. Generally, after the domestic audit, the net profit was higher than that after the overseas audit.

\subsubsection{Difference Trend Analysis}

The difference trend analysis for 2013 to 2015 is summarized in Table 1 below.

\begin{tabular}{|l|l|l|l|l|}
\hline years & $\begin{array}{l}\text { Positive } \\
\text { difference rate }\end{array}$ & $\begin{array}{l}\text { Negative } \\
\text { difference rate }\end{array}$ & $\begin{array}{l}\text { Net difference } \\
\text { rate }\end{array}$ & $\begin{array}{l}\text { Absolute } \\
\text { difference rate }\end{array}$ \\
\hline 2013 & $5.73 \%$ & $-2.07 \%$ & $3.66 \%$ & $7.79 \%$ \\
\hline 2014 & $3.30 \%$ & $-3.41 \%$ & $-0.11 \%$ & $6.71 \%$ \\
\hline 2015 & $3.73 \%$ & $-1.64 \%$ & $2.09 \%$ & $5.37 \%$ \\
\hline
\end{tabular}

Table 1 Analysis of Discrepancies Between Years 2013-2015

In the above table, the positive difference rate is equal to the sum of the positive difference amounts of each company divided by the absolute value of the net profit after taxation within the country's audited reports. The positive difference indicates that the after-tax net profit of overseas audit reports is greater than the amount of net profit after taxation in domestic audit reports; The negative difference is equal to the sum of the negative difference in each company divided by the sum of the absolute value of the net profit after tax in the country's audited report. The negative difference rate means that the after-tax net profit after the overseas audit report is less than the net profit after the domestic market report tax. The net difference rate refers to the sum of the positive and negative difference rates, that is, the net difference between the sum of the net profit after tax of each company's overseas audit report and the net profit after the domestic audit tax return, divided by the absolute value of the after-tax reported net profit within the territory after offsetting the positive and negative difference. Sum. The absolute difference ratio refers to the sum of the difference amount after the absolute value of the 
positive and negative difference is calculated and divided by the absolute value of the net profit after taxation in the domestic trial report.

From 2013 to 2015, the absolute difference rate dropped from $7.79 \%$ in 2013 to $6.71 \%$ in 2004, and then decreased to $5.37 \%$ in 2015 . Therefore, it can be said that the absolute difference in the net profit after tax in domestic and foreign audit reports in the past three years is reduced.

Looking at the net difference again, the net difference rate is the smallest in 2004 and close to zero. In 2013 and 2015, they were 3,6\% and 2.09\% respectively. The overall net difference rate from 2013 to 2015 can also be said to be lower. The decrease in the net difference rate is due to the fact that if the heterogeneity rate decreases year by year. The positive difference rate decreased from $5.73 \%$ in 2013 to $3.73 \%$ in 2015, and the negative difference rate is not clear. The change range is between $-3.41 \%$ and 1.64\%. In addition, compared with 2013, both the absolute difference and the net difference are reduced.

\section{ANWLYSIS OF THE DIFFERENCES IN THE AFTER-TAX NET PROFIT OF LISTED COMPANIES' FINANCIAL AUDITING}

The criteria adopted by overseas accounting firms are international accounting standards, and the accounting firms in China rely on the criteria of China's "Enterprise Accounting Standards" and corporate accounting systems. Although China's accounting system is constantly approaching international accounting standards, there are still very big differences between them.

In addition to the differences in the criteria listed in Table 4 above, the author believes that there are still differences in the direction of audit professional judgment. For example, 1 confirmation of sales revenue and confirmation of expenses. Relatively speaking, overseas certified public accountants will pay more attention to whether the risk of the product has been transferred, and domestic accounting often ignores this condition, and there are similar situations for the confirmation of the cost. 2 For long-term investment and consolidated accounting statements, both the "International Accounting Standards" and the "Accounting Standards for Business Enterprises" stipulate that: When the investment amount accounts for more than 50\% of the invested company's share or does not account for $50 \%$ but has control at the same time, it shall be merged. 3 Asset impairment provision. In five impairment preparation policies

After Taiwan, international accounting standards and Chinese accounting standards should not be much different. Bad debt preparation, long-term investment impairment provision, short-term investment depreciation reserve, and fixed asset value preparation are still quite different. In fact, this difference is caused by differences in the professional judgment of domestic and foreign CPAs.

\section{RESEARCH CONCLUSION AND RECOMMENDATIONS}

\subsection{Research conclusions}

Through the analysis above, we can draw the following conclusions:

(1) In recent years, with the improvement of accounting standards and accounting systems, the level of Chinese certified public accountants and the level of management have been improved to some extent. China's A-shares and B-shares were issued at the same time, and the company's domestic and foreign auditors reported a decrease in the net profit after taxation. The proportion of the two companies is basically the same.

(2) The net profit after tax audited according to the PRC accounting standards and related accounting rules is generally higher than the net profit after taxation adjusted according to international accounting standards. In China, the impact of some items (such as depreciation of fixed assets, loss of fixed assets, long-term investment impairment provision) or items that are difficult to impose (such as cost recognition, capitalization of borrowing interest, and deferred deferred items) are expanding. . This is ostensibly reflected in the differences in accounting standards, which essentially embodies the different ideas of domestic audit. The domestic accountants are mainly audited in accordance with the

“Accounting Standards for Business Enterprises” , and there are often no areas where the guidelines are clear or projects that rely on more professional judgments, which are often not cautious or difficult 
to withstand the pressure of customers. In contrast, although international auditors conduct audits in accordance with international accounting standards and practices, they are more risk-oriented and they are more cautious. As a result, the audited net profits of domestic accountants are often higher than those of overseas audited net profits.

(3) Among the differences, most of them are differences in standards, and a few are differences in professional judgments. Some of the above differences, except for the depreciation of fixed assets, are mostly caused by differences in the criteria.

Overall, the author believes that different auditors have little difference in the quality of the audit. The audit quality of some domestic auditors is still improving, and the difference in net profit after tax is also shrinking.

\subsection{Suggestions}

Based on the analysis of the above-mentioned differences in net profit after taxation of listed companies' financial audits, the author proposes the following suggestions:

1. On the one hand, we must try our best to reduce the differences between China's accounting standards and international accounting standards. On the other hand, we must also consider China's actual national conditions. Our accounting personnel has long been accustomed to relying on existing accounting systems for accounting treatment and lacking the ability to make independent judgments. Given too many options, they will find it difficult to adapt in the short term. Coupled with the specific system of China's securities market, it is easy to generate earnings management manipulation behaviors (such as "arrangement of share placement" and "avoid delisting"). Therefore, when implementing the new system, it is necessary to further refine the requirements of some projects that have a major impact. For example, if the provision for bad debts is made according to the ageing method, it is possible to specify the range of extraction ratios for accounts receivable of different ages.

2 Improve the quality of accounting information disclosure. The differences in the net profits of domestic and foreign audits of A and B shares listed companies do not only depend on the quality of accounting information itself, but also on the quality of disclosure. In the process of collecting sample data, we discovered that there are many problems with disclosure. Some public companies may only disclose the data of the total differences and do not list the specific adjustment items. Some company disclosures are vague, and there are various references such as "quasi-equity" and "reserve withdrawal." This brings great trouble to the investor analysis report. Therefore, it is necessary to strengthen supervision over the dual disclosure of earnings of listed companies. Agreed on the project's disclosure caliber for investors' inspection and supervision.

3. Improve the CPA' s risk control and professional capabilities. For certified public accountants, the state must not stop education for them. Only by continuous learning can the social match be faster and the quality of service can be improved as soon as possible.

\section{REFERENCES}

[1] Li Shuhua; Analysis of the Difference in Net Profit after Tax of Listed Companies' Domestic and Foreign Audit Reports [J]; Chinese CPA; 1997(11)

[2] Tang Songhua, Wu Yuxin; Study on the Differences in Domestic and Foreign Auditing of Financial Listed Companies[J]; Securities Market Herald; 200302

[3] Cai Dagui.Two tax merger influence and coping strategies[J];China Securities Journal;2007 48

[4] Liu Qiang. Talking about the Price-earnings Ratio[J];Foreign Trade Finance and Accounting;2002-02

[5] Dai Kun, Luo Dongfeng. Some Considerations on Withdrawing "Preparation for Falling Prices (Devaluation)"[J];Taxation \& Accounting;1999-06

[6] Chang Zhian, Sarah Perrin; The Advantages and Disadvantages of Non-listed Companies' Voluntary Adoption of International Accounting Standards[J]; China CPA; 2003-12

[7] YANG Shunhua, YANG Haibiao, Wolfgang Miller; EU accounting internationalization process 
and inspiration[J]; Financial and Economic Theory and Practice; 2004-06

[8] Qiao Yuanfang; The European Community requires all listed companies to use international accounting standards before 2005[J]; Shanghai Accounting; 2001-04

[9] Cui Junlian, Chen Yu; Problems and Countermeasures in Information Disclosure of Listed Companies[J]; Zhongzhou Auditing; 1998-10 